\title{
Disciplinary competencies in mathematics: Perception of General Basic Education Teachers regarding their initial training process
}

\author{
${ }^{1}$ Aravena Ramírez, Lorenzo D., ${ }^{2}$ Cornejo Espejo, Juan., ${ }^{3}$ Gajardo-Asbún, Karen P. \\ ${ }^{1}$ Candidato a Doctor en Doctorado en Educación en Consorcio. Universidad Católica del \\ ${ }^{2}$ Académico, Departamento Ciencias de la Educación. Universidad del Bío Bío \\ ${ }^{3}$ Académica, Facultad de Ciencias de la Educación. Universidad de Talca. \\ 11aniel.aravena1881@gmail.com, ${ }^{2}$ jcornejo@ubiobio.cl, ${ }^{3}$ gkaren.gajardo@utalca.cl
}

Article History: Received: 11 January 2021; Accepted: 27 February 2021; Published online: 5 April 2021

\begin{abstract}
This research reveals the perception of teachers in General Basic Education Pedagogy regarding the disciplinary competencies in the subject of mathematics achieved during their initial training process. The results of the interviews applied to these professionals show a dissatisfaction with the mathematical knowledge received, considering that this has generated difficulties in their professional development since, from the perspective of the interviewees, higher education institutions did not fulfill their training role in this subject area.
\end{abstract}

Keywords: Initial Teacher Training, Competences, Mathematics.

\section{Introduction}

Both internationally and in Chile, the concern for the role of teachers has not been absent in the educational discussion (Morales, 2018; Piñero Charlo, 2020; Vanegas Ortega and FuentealbaJara, 2019), since vital importance is given to the impact that teachers have on society (Gajardo-Asbún, 2019). The discussion increases with the publication of the OECD report on the Chilean educational system, evidencing the shortcomings it presents (OECD, 2004), among them the teaching of the discipline, this due to the great impact it has on the achievement of learning objectives by students (Cuadra, 2009; Vaillant, 2016). Then, once again, the topic becomes important when it is reflected in the conclusions presented by the Presidential Advisory Council for the Quality of Education (2006), where it is established that initial teacher training is a limiting factor for the achievement of an excellent education, which is why the need for the development of a professional teaching career is proposed.

Another element highlighted by the report is the weak initial training of mathematics teachers who teach in General Basic Education, and according to the results of the TEDS-M evaluation, Chile ranks second to last among the participating countries (Astudilloet al., 2011). This is also evidenced by the results of the National Diagnostic Evaluation (END) of 2014, which shows that one third of the graduates did not reach a rank higher than $75 \%$ of correct answers in the test of disciplinary knowledge (Pedrajaet al., 2015).

The results of TEDS-M and the END present an analysis of initial teacher training at both international and national levels from a quantitative epistemological approach, so it is pertinent to ask from a qualitative approach, what is the perception of teachers of General Basic Education Pedagogy graduated from universities located in the Maule region, regarding the level of mastery of disciplinary competencies in mathematics achieved in their initial training process? In order to answer this question, it is necessary to know the definition of mathematical competencies. For the development of this study, the definition proposed by the Programme for International Student Assessment was adopted (PISA) (2014):

Mathematical competence is an individual's ability to identify and understand the role of mathematics in the world, make informed judgments, and use and relate to mathematics in ways that meet the needs of individuals' lives as constructive, engaged, and reflective citizens (p. 21).

The conception of competence refers to a series of skills that people should develop during their time in the educational system, as they are constantly being updated due to social changes (Díaz et al., 2020; Sartor-Harada et al., 2020). In educational establishments, it is the teachers who plan the interaction between the pre-established curriculum, the context and their students. At the end of their teaching process, students must be able to solve concrete problems of everyday life, putting into practice what they have learned and demonstrating that they have achieved certain competencies (Aguerrondo, 1999). Therefore, the Organization of Ibero-American States (2016) proposes that learning developed in a repetitive and mechanical way limits the achievement of skills; therefore, it evidences the need for the development of competency-based instructional processes, since these are produced in interaction between previous knowledge, and the new learning to be achieved. These approaches focus on teachers, since they have the mission of generating learning in the classroom and in order to develop this task in an optimal way, they must be competent in the disciplinary area they teach.

\subsection{Disciplinary Competencies in Mathematics}

The definition of mathematics adopted for the development of this study is the one proposed by Rico (2005), who states that mathematics in the educational system represents a series of operations that exhibit an interaction and relationship, whose mastery requires solid and deep knowledge of this discipline. 
This mathematical knowledge is what is demanded of the teacher of General Basic Education in order to perform in the classroom, and thus be able to optimally develop the task of teaching at a given school level (Perrenoud, 2005). In this context, the Chilean Ministry of Education has issued a series of regulations that provide guidelines on the mathematical competencies that pedagogy graduates should possess and that should be achieved during their training process: Standards for Initial Teacher Training, Curricular Bases, Study Programs from 1st to 6th grade, and the contents evaluated in the SIMCE, PISA and TIMSS tests.

The mathematical knowledge that teachers should possess should go beyond the school curriculum, since it will allow them to face emerging challenges in the classroom and be prepared for the curricular changes that will occur throughout their professional performance (Medina, 2011). In Chile, the Ministry of Education (2011) has defined disciplinary knowledge as "knowing the discipline being taught", which includes concepts, procedures, representations, problem solving, reasoning and mathematical language.

In this sense, the Ministry of Education (2008), after a joint work with several educational agents, published the Framework for Good Teaching (FGT) where four domains were established that refer to each of the moments of a class: planning and preparation of teaching; creation of environments conducive to learning; the teaching itself, and finally the evaluation and reflection on the process carried out in its entirety. The objective of this document was to provide guidelines for the institutions that train future teachers and at the same time establish the basic principles for quality initial teacher training in the different pedagogical disciplines (Avalos, 2014). Under this same premise, after some years, this institution proposed the Guiding Standards for Graduates of Basic Education Pedagogy, which "indicate everything that the teacher must know and know how to do to perform satisfactorily in the different roles and scenarios involved in the exercise of teaching" (Ministry of Education, 2011, p 92), for which this research has focused on only one of them: disciplinary competence.

\section{Methodology}

The objective of this research is to know the perception of Basic General Education teachers about the disciplinary competences achieved in their initial training process in the subject of mathematics.

The research is ascribed under an interpretative paradigm (Pérez, 2004), since it seeks to deepen the knowledge and understanding of the reason for a reality (Torres, 2006). The epistemological approach, as Bisquerra (2004) points out, is qualitative, which is characterized by studying a concrete situation in depth, does not seek explanation or causality, but understanding, and can establish plausible inferences between the configuration patterns in each case. The case study was used (Bisquerra, 2004), since the number of people with whom the study was carried out was limited, and the aim was to rescue the appreciations, opinions and/or meanings that they attribute to the reality in which they work.

The participants were graduates of Pedagogy in General Basic Education during the years 2011, 2012 and 2013, belonging to three institutions of higher education located in the Maule region of Chile. The case studies were represented by a total of eighteen teachers.

In relation to the data collection procedure, the participants were working in an educational establishment, teaching mathematics classes in elementary education. All of them answered a semi-structured interview, composed of five questions, focused on the disciplinary dimension. The script of questions was submitted to the judgment of experts, who analyzed for each one of them, the sufficiency to achieve the research objective, its clarity to be raised and answered by the interviewee, also evaluating the relevance in relation to others, all this in order to obtain clear and reliable information (Bisquerra, 2004).

For the interpretation of the data, qualitative content analysis was chosen according to Philipp Mayring's (2000) understanding, which can be defined "as an empirical approach of methodologically controlled analysis of texts within their communication contexts, following content analytical rules and step-by-step models, without quantification" (p. 4). That is to say, this type of analysis implies a systematic, orderly and interpretative process of the data that involves the fulfillment of a series of steps of deductive-inductive development, which leads to the construction of categories of analysis. The steps used are the following:

a) The perceptions of Basic General Education teachers regarding the disciplinary competencies attained in their initial training process were defined as the objective of analysis.

b) The units of analysis were the disciplinary competencies of the Basic General Education teachers, with respect to the disciplinary competencies attained in their initial training process.

c) The classification codes were produced on the basis of the interviewees' statements.

\section{Results}

The findings of this study are organized into six categories of analysis, which respond to the research objective. The units of analysis are represented in Figure 1, and will be described later together with their analysis. 


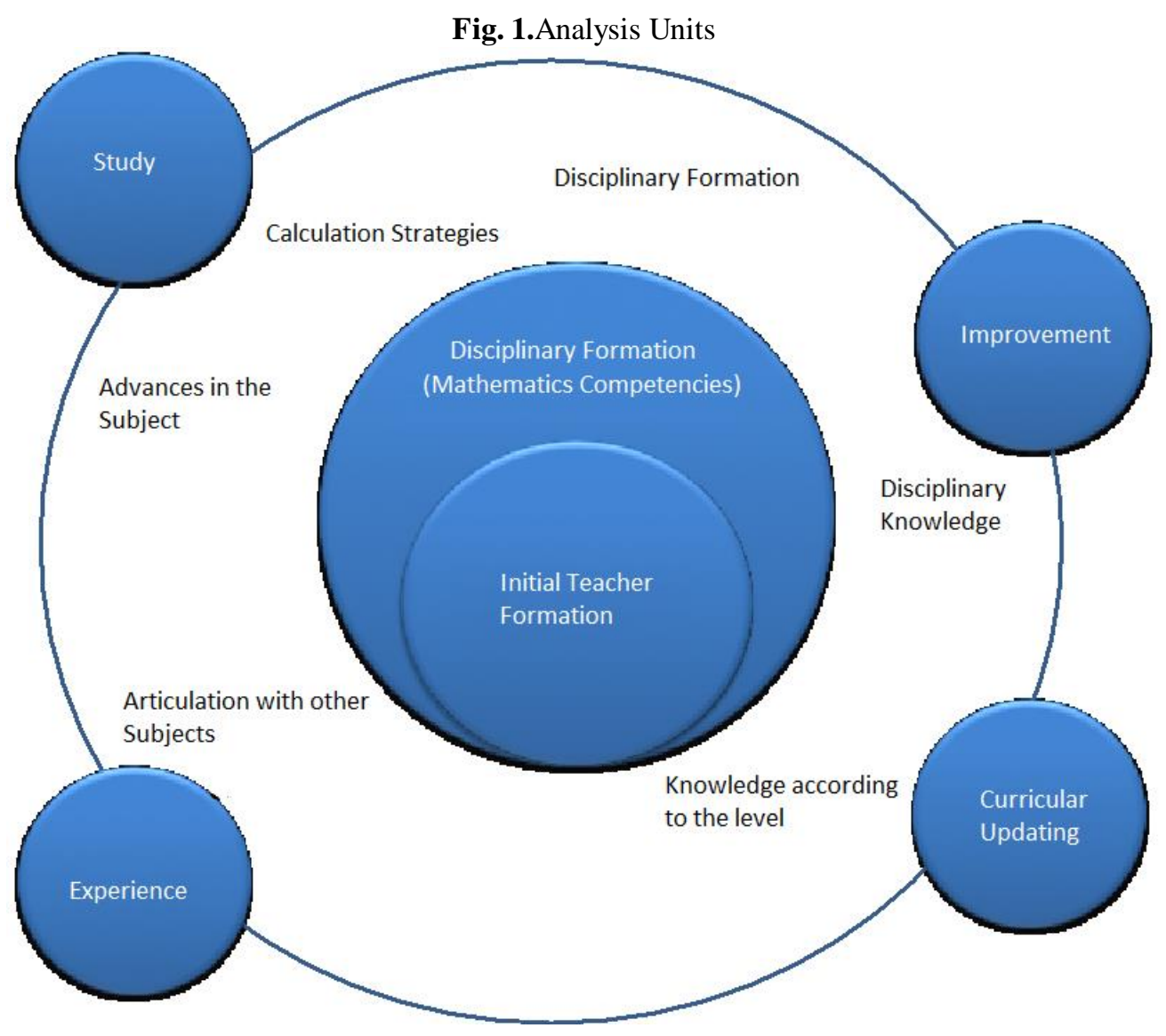

A first element that emerges from the analysis of the interviews are the demands regarding what is expected of the mathematics teacher today. The United Nations Educational, Scientific and Cultural Organization (UNESCO) points out that expectations are higher every day. According to this organization, there is a growing demand for better academic skills and it points out the need for teachers to continuously update their pedagogical skills as well as their disciplinary knowledge (Percovich, 2012).

\subsection{Advances in the discipline}

The teaching of mathematics in recent years has undergone a change at the curricular level, since, with the current educational reform, the contents were rethought, lowering some of the level at which they were previously taught, so that each teacher has had to be informed of the changes that were generated and also incorporate these new contents into their class planning.

"I don't think so, besides, there have been several advances in terms of teaching, practically leaving behind the plans and programs, for example, which was the main thing we were taught" (IES112)

According to the interviewee, university education presents a gap between the knowledge that is taught and the changes that these undergo in today's education. Therefore, once each teacher finishes his or her training process at the university and enters the working world, he or she already has deficiencies that must be faced and solved in order to have a good professional performance.

"No, no because the whole period I had mathematics was in a year and a half, so it was always like covering the same thing, if you ask me now, there are differences, they are changing everything, but in that period, I was not taught" (IES210)

The changes that have occurred in the subject of mathematics have occurred not only in relation to the level at which content is taught, but also in the way it is presented to students in the degree of complexity that must be taught.

"We did not receive training, it was always general orientations, but in mathematics it was always to the concrete material" (IES312)

The teaching-learning process in mathematics should be related to the advances in the discipline and should not only be based on mere disciplinary knowledge updated in isolation, but should also seek to develop meaningful learning in students through the use of strategies and didactic materials in line with the advances in the discipline, for which the teacher must be familiar with and be able to contextualize the knowledge. 
"Although I was presented with several teaching-learning strategies that were supposed to be key to teach the contents of the subject of mathematics, when I took them to the real context of what it is like to teach classes today, they were not congruent with what the contents are today" (IES311)

Every teacher must know the various teaching strategies and the pertinent didactic material for each one of them, since this way he/she will be able to make a correct selection, and thus will be able to confront his/her students with a diversity of strategies. Nowadays, students have greater access to new technologies, a situation that has generated that the teacher must master these technological innovations, to put them at the service of their pedagogical objectives. Thus, each teacher will be able to face the development of a class, prepared from different areas, to achieve learning in all his students.

\subsection{Disciplinary knowledge}

As stated in some studies, no one can teach what he/she does not know, therefore, for a teacher who teaches mathematics it is extremely important that he/she masters the contents of the discipline, which in this case are organized into six thematic cores: numbers and operations, patterns, algebra, geometry, measurement, data and probabilities, working transversally on problem solving. This is the only way to understand the skills that must be developed in students so that, at later levels, they can develop other higher-level skills.

"Yes, the university helped me to solve different problems, it strengthened my mathematical and strategic language" (IES111).

The mastery of the discipline being taught is also linked to the mastery of a series of mathematical concepts that allow students to develop the basic skills for learning certain content, which will be the basis of all mathematical learning. Because of this, it is very important that the teacher masters the mathematical concepts and their main ideas when teaching them to his students.

"We were supposed to have had a mathematical language course, which had to do with a language that was supposed to bifurcate into these two as subtopics, but even so, I feel that what we were taught is not useful for a first or second grade class" (IES212)

The teaching of mathematics starts from the basics, such as number recognition, to the development of complex arithmetic operations and beyond. A teacher who comes from a generalist training program, who can currently work up to sixth grade and depending on the establishment up to eighth grade, should be able to teach students at all these levels.

"In the first cycle I feel very confident with what I learned in my university education, very confident in the contents, but I must admit that in the second cycle I do not, because the contents have advanced a lot compared to when I studied. The contents are being updated and changing" (IES110)

As stated by the interviewee in the previous paragraph, every discipline presents advances and updates, mathematics is no exception to this and over the years a series of new methodologies and materials have been presented that allow students to achieve greater learning. For this reason, teacher training programs must be updated and those in charge of training new teachers must also be part of this update.

"No, on the contrary, the teachers who taught us mathematics were very old, very square teachers, who didn't give us more, relating it to today, it was always something very square and basic" (IES312)

The Ministry of Education, together with the Center for Advanced Research in Education (CIAE- Centro de Investigaciones AvanzadasenEducación) of the University of Chile and the Center for the Study of Policies and Practices in Education (CEPPE - Centro para el Estudio de Políticas y PrácticasenEducación) of the Pontificia Universidad Católica de Chile, developed the standards that seek to guide universities to reform their training programs. Based on these standards, the contents that will be evaluated in the NDT, which all pedagogy graduates take, are taken and, in the future, according to the results obtained in this evaluation, will determine whether or not the graduate is qualified to work in a public education institution.

\subsection{Calculation strategies}

Teachers must master a series of calculation strategies, mental or written, in order to teach their students, who must select the form that allows them to achieve the result in the clearest and easiest way for them, regardless of the level at which they are teaching.

"But I repeat, I feel that the first cycle gave me a good formation to face mathematical contents, calculations and procedures in this area." (IES110)

A teacher who is able to justify the properties and validate computational algorithms and efficiently perform operations using alternative methods, so that his students possess a varied range of methods, will be able to develop in his students the skills needed to perform operations of greater complexity. 
"No, although I was taught several calculation procedures in the area of mathematics, I believe that they were not enough considering that the General Basic Pedagogy career lasts 5 years" (IES311)

The initial teacher training offered in the Maule region comes from three different universities and is reflected in the curricula of the training programs offered by these higher education institutions. Each institution has dissimilar characteristics, with different graduate profiles, weaknesses and strengths that must be overcome or strengthened according to the educational reality where they work, and according to the experience they acquire during their daily pedagogical practice.

"Yes, he did teach me, as I was telling you before, the classes were based on developing exercises with different procedures, so I was able to manage several strategies, which I have used with my students up to now." (IES212)

The teaching-learning process, when faced with a solid disciplinary base and in addition the teacher possesses varied teaching strategies, will allow his students to develop varied calculation processes that will allow them to find the answer to the questions posed from various perspectives, all according to the skills that each student possesses.

"Yes, a lot, especially in what I was saying, addition and subtraction strategies, and not only for the youngest ones" (IES211)

If a teacher acquires a series of mental or written calculation strategies during initial training, he/she will be able to select the most pertinent to the reality of his/her students, considering the level of abstraction that they present, and the context in which the school is immersed. In addition, by applying these strategies, the teacher will acquire the experience that will allow him/her to know which strategies are the most pertinent for each educational level and context. Also, the interaction with other teachers will allow them to share their knowledge and also to acquire other strategies that have already been validated by the teachers in their classes.

\subsection{Knowledge according to the level taught}

Students see their teachers as referents of information; for this reason, what they teach must be accurate, without conceptual errors, so that the particularities of the disciplines are respected. Regardless of the teaching strategy they use, they must know the complexities and concepts involved in the content they teach. This will allow them to offer their students a rigorous and clear approach to the topics addressed in class.

"I think it allowed me to know and handle the different perspectives of mathematics, since I

had a great foundation in my career that allow me today to be a good professional" (IES110).

Content knowledge is different for teachers at different levels of education. Teachers who teach a single discipline have more specialized knowledge than generalists who teach several subjects. For example, first cycle teachers who teach most subjects should have knowledge and skills on how to teach reading and writing, the teaching of elementary mathematics, and on understanding the natural and social environment.

"Yes, we made many comparisons, how it was taught before, the difference between mathematics, mathematics education, how it was taught before and how it is taught now. The types of students we have now are very different from those of our generation" (IES211).

The level of understanding that teachers must have of the discipline they teach and the relationship of its central concepts with other disciplines at each level must be in accordance with what is set forth in the national curriculum, where the learning that they are committed to achieve in their students is made explicit.

"It allows you to have a global vision of the advances of this science, since it is a science in constant construction and reformation." (IES310)

In addition, teachers are faced with the latent challenge of the advances in the field, as it evolves over time, it is updated, given the permanent and rapid evolution of the disciplines. For this reason, teachers must keep themselves informed of new developments in their field.

\subsection{Articulation with other subjects}

Articulation requires the teacher to be able to give examples or generate applications of the content he/she teaches in relation to other subjects, exposing students to situations similar to those they face when solving a real problem.

"Yes, there were branches that instilled in us the transversality of learning, given by understanding that mathematics is a science of daily use and almost involuntary, that in each of the things that are done you can see a little of it, from something as basic as making a cup of milk, to understanding ancient civilizations" (IES310).

By knowing the relationship of the central concepts of the discipline being taught with other related disciplines, bridges can be built that allow students to understand a phenomenon from different points of view.

"...geometry in mathematics, then building geometric figures in technology, drawing nets in arts, etc... It teaches us to be able to use a content and connect it with the various disciplines" (IES110). 
Working the contents in an articulated way allows students to see the usefulness of the content not only in an isolated way in the subject, but also allows them to relate it to their daily life, generating a learning process that lasts over time.

"All the areas that one teaches can be intertwined, the contents are made so that one can join them and/or create united knowledge." (IES111)

The teacher must know how to connect the contents of the subsectors he/she teaches with the students' lives, with the personal, social, cultural and work contexts they know and to which they will have access when they graduate from the educational process.

"I remember there was a teacher who used to say: a child who has integrated mathematical concepts would burp mathematically at the slightest touch, for example, in natural science he can perfectly well use the units of measurement used in an experiment and rely on the conversion systems that second cycle students know" (IES310).

The objective of the school experience is to develop skills to manage information, remember it, understand it and use it. Only in this way will students be able to have a level of understanding, to relate units of knowledge in contexts greater than their reality and in other educational contexts.

\subsection{Disciplinary Formation}

"You cannot teach what you do not know" (MINEDUC, 2004, p.16). This statement captures the essence of why content knowledge is important for teaching. Although it is necessary to clarify that the term content includes much more than factual information, it encompasses all aspects of a discipline: its concepts, principles, relationships, methods of inquiry, processes of creation, and relevant elements are all part of what teachers teach their students in their classrooms.

"Always the reasoning, problem solving drags the level of understanding of the people, within the university workshops are created and in the subjects the professors make you work hard to develop your skills in your benefit" (IES110.)

The initial training process is vital for the teacher to acquire the disciplinary competencies necessary to teach mathematics, as well as the pedagogical principles and competencies needed to organize the teaching-learning process, all in the perspective of engaging and educating all students, within the specific particularities of the context in which this process takes place.

"When presenting the difficulties to the teachers it was practically one's responsibility to adapt all this idyllic to reality, to make it magical, to make it ideal, that with love everything is solved, and this was never the case." (IES312)

In this sense, teachers must have a deep understanding of the disciplines they teach and of the knowledge, competencies and pedagogical tools that facilitate an adequate mediation between the contents, the students and the respective learning context. However, neither mastery of the discipline nor pedagogical competencies are sufficient to achieve quality learning; teachers do not teach their discipline in a vacuum, they teach it to specific students and in specific contexts, whose conditions and particularities must be considered when designing teaching activities. For these reasons, teachers need to be familiar with the developmental characteristics corresponding to the age of their students, their cultural and social particularities, their experiences and knowledge, skills and competencies with respect to the disciplines they teach.

\section{Discussion}

Practicing teachers face the daily challenge of developing meaningful learning in their students, considering all the advances that mathematics presents daily, in addition to the constant search to overcome the shortcomings that were generated during their initial training, and according to what the interviewees themselves say, they are aware of this and have sought to overcome them by studying the content to be taught to their students beforehand.

This requirement is manifested in the definition of competencies provided by the test PISA (2014):

"Mathematical competence is an individual's ability to identify and understand the role of mathematics in the world, make informed judgments, and use and relate to mathematics in ways that meet the needs of individuals' lives as constructive, engaged, and reflective citizens." (p.16)

This conception poses to teachers the demands of the educational system so that they can perform in a competent manner. According to those interviewed, they identify deficiencies that they have tried to overcome by accessing further training, where, in addition to broadening their disciplinary knowledge, they have been able to learn about other teaching strategies that were not addressed when they were in their initial training process. The General Basic Education teachers interviewed have gained valuable experience, which allows them to identify the need for new teaching methods, recognizing that the students with whom they work need them. In this sense, disciplinary knowledge is essential, it is considered in what is called Knowing the Discipline to 
Teach, which includes concepts, procedures, representations, problem solving, reasoning and mathematical language (Ministry of Education, 2011).

"Knowing something allows us to teach it; and knowing a content in depth means being mentally organized and well prepared to teach it in a general way " (Buchmann, 1984).

The knowledge possessed by teachers in training and in practice should not be seen as something isolated from the culture, context and previous knowledge they possess. In relation to Onetto (2003), teachers, as their classroom experience increases, attribute greater relevance to the interdisciplinary nature of the contents, since if the teaching-learning process is developed in an articulated manner with other disciplines, students better identify the usefulness of this new learning for their daily life. This can be facilitated or limited by teachers because they must know the progression of the contents in the national curriculum and educational levels.

The mastery of the competencies that General Basic Education teachers should have once they graduate from their schools is incorporated in the standards for initial teacher training, since they provide guidance on the knowledge and skills that a teacher education graduate should have in order to teach this discipline, based on the criteria of experts. It is also understood that it is possible to develop different academic paths or trajectories for teachers to achieve these standards. In addition, these standards assume that the basic cycle teacher will teach, fundamentally, in four disciplinary areas: Language and Communication; Mathematics; History, Geography and Social Sciences; and Natural Sciences.

The interviewees are familiar with the guiding instruments, on the basis of which the NDT has been created, a system established by the Ministry of Education, with the purpose of verifying the quality of Initial Teacher Education. The participants of the research show a weak disciplinary training, which they have been able to overcome by improving themselves and studying each content that they believe was weakly delivered or not taught during their initial training program, in order to face the teaching-learning process in a competent way.

\section{Conclusions}

According to the analysis carried out, the following conclusion was generated to answer the research question: What is the perception of teachers of General Basic Education Pedagogy, graduates of universities located in the Maule region, regarding the level of mastery of disciplinary competencies in the subject of mathematics achieved in their initial training process?

The teachers interviewed in this area indicate that the initial training process they received does not respond to the current demands for a teacher of General Basic Education who teaches the subject of mathematics. They state that they did receive training in the discipline, but it did not allow them to be able to teach their students, since it lacked a relationship with the national curriculum.

Mathematics is a discipline that is constantly being updated, which is why the interviewees stated that, upon graduating from their universities, they had to seek mechanisms to update the contents they handled and thus be in line with the needs demanded by the current educational system.

It is very important for a teacher to have a good command of the discipline he/she teaches, since this is the only way to make a correct diagnosis of the level of depth with which he/she should work on the content, the most appropriate teaching strategies for it, and the relationship he/she can make with other subjects, since the teaching-learning process is not isolated. This last point also marks one of the weaknesses expressed by the interviewees, since within the low disciplinary training they claim to have received, it is incorporated that the contents taught were presented in isolation, without a relationship with the environment or other subjects of the curriculum, as stated in the Framework for Good Teaching (2008). Although the interviewees did not state in their entirety that their initial training was deficient, what is reiterated the most in this aspect is the lack of connection between learning modules, which would have allowed them to be better prepared at the time of practicing the profession.

The interviewees express that these shortcomings were identified once they were inserted in the educational centers; this issue is mentioned by all the interviewees. That is, once they were practicing the pedagogy for which they had been prepared, they recognized that there were areas for which they did not feel competent.

Based on the results of this research, it can be observed that higher education institutions that train teachers still have the great task of updating their training programs, using the Performance Standards for Initial Teacher Training and the Framework for Good Teaching as a reference point.

In the light of what has been stated in the previous paragraph and after the research has been carried out, it is necessary to think about future proposals for possible studies related to initial training, since it is interesting to investigate topics such as: didactic strategies used by academics in the faculties of education in their teaching practice.

\section{References}

1. Aguerrondo, I. (1999). El nuevo paradigma de la educación para el siglo. Organización de Estados Iberoamericanos para la Educación, la Ciencia y la Cultura. 
2. Astudillo, J. M., Secundarios, I., Román, P. L., Gerard, L. M., Moore, I. R., Sandoval, P. P., y Gutiérrez, E. S. M. (2011). ¿Qué características de la formación inicial de los docentes se asocian a mayores avances en su aprendizaje de conocimientos disciplinarios?

3. Ávalos, B. (2014). La formación inicial docente en Chile: Tensiones entre políticas de apoyo y control. Estudios pedagógicos (Valdivia), 40(ESPECIAL), 11-28.

4. Ávalos, B. y Matus, C. (2010) La formación inicial docente en Chile desde una óptica internacional. Informe nacional del Estudio Internacional IEA TEDS-M. Ministerio de Educación.

5. Babcock, J., Babcock, P., Buhler, J., Cady, J., Cogan, L., Houang, R., Kher, N., Patrick, J., Rosolova, K., Schmidt, W. \& Wight, K. (2010), Breaking the cycle an international comparison of U.S. mathematics teacher preparation. Initial findings from the Teacher Education and Development Study in Mathematics (TEDS-M). The Center for Research in Math and Science Education, Michigan State University.

6. Bisquerra Alzina, R. (2004). Metodología de la investigación educativa. Editorial La Muralla, S.A.

7. Brousseau, G.(1998). Problemes de didactique des décimaux.Recherches en Didactique des Mathématiques, Vol. 2, 37-127.

8. Chevallard, Y. (1990). Le passage de l'arithmétique A l'algebre dans l'enseignement des mathématiques au college, Petit X, 19, pp. 43-72.

9. Cox, C., Beca, C. E., y Cerri, M. (2014). Docentes para una educación de calidad en América Latina: problemas y orientaciones políticas. Realidades y Prospectiva Educativa, 41-92.

10. Cuadra Martínez, D. (2009). Teorías subjetivas en docentes de una escuela de bajo rendimiento, sobre la enseñanza y el aprendizaje del alumno. Revista mexicana de investigación educativa, 14(42), 939-967.

11. Díaz, M., Romero-Jeldres, M., Mardones, T., Castillo, S.,y Sequeida, R. (2020). Competencias didácticas para la formación inicial de profesores de Chile. Un análisis comparado. Sophia Austral, (25), 53-70. https://dx.doi.org/10.4067/S0719-56052020000100053

12. Freudenthal, H. (1991). Revisiting Mathematics Education. Kluwer Academic Publishers.

13. Gajardo-Asbún, K. (2019). Estado del arte sobre identidad docente: investigación de experiencias de profesores en formación y en ejercicio. IE Revista de Investigación Educativa de la REDIECH, 10(18), 79-93. https://doi.org/10.33010/ie_rie_rediech.v10i18.217

14. Hernández Sampieri, R., Fernández Collado, C. y Baptista L. (2006). Metodología de la investigación. (2a ed.): McGraw-Hill Interamericana Editores, S. A.

15. Larrondo, T., Lara, M., Figueroa, C., Rojas, M. y Caro, A. (2007). Desarrollo de Habilidades Básicas en Lenguaje y Matemáticas en Egresados de Pedagogía. Un Estudio Comparativo., Revista Calidad en la Educación, No. 27, 150-176.

16. Márquez, A., M. (2014). La educación de talentos en la formación inicial docente como factor de inclusión, equidad y movilidad social: investigación diagnóstica y propuesta de innovación para fortalecer la formación inicial docente.

17. Medina, M. A. (2011). Conocimiento y Uso de las Estrategias Didácticas de Enseñanza para el Aprendizaje Significativo de las Matemáticas por Docentes de Educación Secundaria-Edición Única.

18. Ministerio de Educación. (2008). Marco para la Buena Enseñanza. CPEIP.

19. Ministerio de Educación. (2011). Estándares Orientadores de Pedagogía en Educación Básica. LOM Ediciones Ltda.

20. Morales, H. (2018). Influencia de un Proceso de Formación de Profesores en el Sistema de Enseñanza del Concepto de Área en Estudiantes de Pedagogía en Matemáticas, un Estudio de Caso. Bolema: Boletim de Educação Matemática, 32(62), 1050-1067. https://doi.org/10.1590/1980-4415v32n62a15

21. OCDE. (2004).Revisión de políticas nacionales de educación. OCDE y Ministerio de Educación de Chile.

22. Onetto, F. (2003). Criterios de intervención en las problemáticas de convivencia escolar. Convivencia escolar y calidad de la educación. Maval, 97-112.

23. Organización de Estados Iberoamericanos. (12 de abril de 2016). http://www.oei.es/index.php. Obtenido de http://www.campus-oei.org/administracion/aguerrondo.htm

24. Osses Bustingorry, S., Sánchez Tapia, I., y Ibáñez Mansilla, F. M. (2006). Investigación cualitativa en educación: hacia la generación de teoría a través del proceso analítico. Estudios pedagógicos (Valdivia), 32(1), 119-133.

25. Pedraja-Rejas, L. M., Araneda-Guirriman, C. A., Rodríguez-Ponce, E. R., y Rodríguez-Ponce, J. J. (2015). Calidad en la formación inicial docente: evidencia empírica en las universidades chilenas. Formación universitaria, 5(4), 15-26.

26. Percovich Castelo, H. J. (2012). Las Competencias personales de los docentes, en Educación Básica. una mirada desde la Gerencia de Aula (Master's thesis).

27. Pérez Serrano, G. (2004). Modelos de investigación cualitativa en educación social y animación sociocultural: aplicaciones prácticas. Narcea. 
28. Perrenoud, P. (2005). Diez nuevas competencias para enseñar. Educatio Siglo XXI, 23, 223-229.

29. Pinto, H. (2011). Formación de competencias docentes en matemática de educación básica. Cuadernos de Educación y Desarrollo, 3, 26.

30. Piñero Charlo,J. (2020). Modelando los diferentes roles del docente en la educación matemática moderna.RevistaEspacios, Vol. 41 (30) https://www.revistaespacios.com/a20v41n30/20413025.html

31. Programme for International Student Assessment (PISA). (2015). http://www.oecd.org/pisa/. Obtenido de https://s3.amazonaws.com/archivos.agenciaeducacion.cl/documentosweb/Estudios+Internacionales/PIS A/Informe_Nacional_Resultados_Chile_PISA_2015.pdf.

32. Rico, L. (2005). Valores educativos y calidad en la enseñanza de las matemáticas. En J. M. Martínez (Ed.), Matemáticas, investigación y educación. Un homenaje a Miguel de Guzmán (pp. 158-1809).

33. Sartor-Harada, Andresa, Azevedo-Gomes, Juliana, Pueyo-Villa, Silvia, \& Tejedor, Santiago. (2020). Análisis de las competencias docentes en proyectos de aprendizaje-servicio en la educación superior: La percepción del profesorado. Formación universitaria, 13(3), 31-42. https://dx.doi.org/10.4067/S0718 50062020000300031

34. Tejada, J. (2013). La formación de las competencias profesionales a través del aprendizaje servicio. Cultura y educación, 25(3), 285-294.

35. Torres, C. A. B. (2006). Metodología de la investigación: para administración, economía, humanidades y ciencias sociales. Pearson educación.

36. UNESCO. (1990). http://www.unesco.org/. Recuperado el 20 de Julio de 2017, de http://www.unesco.org/education/pdf/JOMTIE_S.PDF

37. Vaillant, D. (2016). Algunos marcos referenciales en la evaluación del desempeño docente. Revista Iberoamericana de Evaluación Educativa, 1(2).

38. Vaillant, D. (2016). El fortalecimiento del desarrollo profesional docente: Una mirada desde Latinoamérica. Journal of Supranational Policies of Education.

39. Vanegas Ortega, C. y Fuentealba Jara, A. (2019). Identidad profesional docente, reflexión y práctica pedagógica: Consideraciones claves para la formación de profesores. PerspectivaEducacional, 58(1), 115-138. https://dx.doi.org/10.4151/07189729-vol.58-iss.1-art.780 